\title{
Risk Factors For The Presence Of Artemisinin Antibodies Amongst Patients Undergoing Treatment For Malaria In Benin City, Nigeria
}

\author{
Helen Oroboghae Ogefere, Nosakhare Lawrence Idemudia, and Richard Omoregie
}

\begin{abstract}
Artemisinin have being used for the control of malaria worldwide for over a decade and its listing by WHO as the first-line drug for treatment of both severe and uncomplicated malaria and the observed treatment failure have warranted the need to screening malaria patients for the presence of antibodies to malaria. In our locality where there is unregulated use of antimicrobials, the need to ascertain the prevalence of antibodies to artemisinin and evaluate the potential risk factors cannot be overemphasised, hence this study. Blood specimens were collected from 400 randomised patients undergoing treatment for malaria in Benin City, Nigeria. Data on socio-demography were collected with the aid of a well-structured questionnaire. Artemisinin antibodies were detected by drug absorption mechanism (DAM) and immune complex reaction (IMC) methods. ABO, rhesus blood group, and haemoglobin (Hb) phenotype were determined by using standard technique. A total of $112(28.00 \%)$ out of the 400 participants had artemisinin antibodies. Gender, marital status, level of education, residential area and living arrangement did not significantly affect the prevalence of artemisinin antibodies whereas age and ethnicity significantly affected the prevalence of artemisinin antibodies ( $p=0.0244$ and 0.0001 respectively). Duration of the last artemisinin used and the mostly used brand of artemisinin as well as the $\mathrm{ABO}$ and rhesus blood groups and haemoglobin phenotypes did not significantly affect the production of artemisinin antibodies. Although of all the risk factors age and ethnicity were identified as the only risk factors for the development of artemisinin, we therefore advocate the prudent use of artemisinin-containing antimalarial and concerted efforts in combating self-medication with this drugs to avoid the development of resistance.
\end{abstract}

Index Terms-Antibodies; Artemisinin; Prevalence; Risk factors.

\section{INTRODUCTION}

Malaria is an infectious disease caused by a microscopic parasite known as Plasmodium spp. which is transmitted between humans by mosquitoes [1]. It is known to be the cause of 216 million reported cases of illness and 445,000 deaths in 2016 with about $90 \%$ of this morbidity and mortality cases domiciled in Sub-Sahara Africa [2]. Malaria is a risk for $97 \%$ of Nigeria's population. The remaining $3 \%$

Published on June 15, 2020

H. O. Ogefere, University of Benin, Nigeria.

(email: Helenogefere@gmail.com).

N. L. Idemudia, University of Benin Teaching Hospital, Nigeria

(corresponding e-mail: lawnosa@gmail.com).

R. Omoregie, University of Benin Teaching Hospital, Nigeria.

(e-mail: Richard.omoregie@ubth.org). of the population live in the malaria free highlands [3]. Malaria can be a severe, potentially fatal disease (especially when caused by Plasmodium falciparum) with symptoms ranging from high fever, chills, flu-like illness etc [4].

Anaemia is a known complication of malaria and over half of malaria related deaths are attributable to severe anaemia [5], [6]. The goal of most current National Malaria Control Programs and most malaria activities is to reduce the number of malaria-related cases and deaths. The fight to reduce malaria transmission to a level where it is no longer a public health problem have led to the use of anti-malaria drugs worldwide [4]. Due to high resistance to most antimalaria drugs, artemisinin based combination therapy are recommended as first line treatment for falciparum malaria [7]. Resistance to artemisinin has been reported in SouthEast Asia [8], [9]. In Nigeria, antimicrobial use is unregulated and over the counter sales of anti-microbial agents without prescription are common [10]-[12]. This selective pressure can result in drug resistance and antibody formation. Indeed, autoimmune haemolytic anaemia resulting from artesunate administration have been reported [13]-[16]. A recent report has demonstrated the presence of artemisinin resistant P. falciparum in Africa [17]. Another recent study demonstrated the presence of antibodies to sulphadoxine in our environment [18]. However, to the best of our knowledge no study has been done to ascertain the risk factors and determine the presence of artemisinin antibodies in our locality.

Therefore, this study aimed to determine the prevalence of artemisinin antibodies among patients with malaria and also determine the impact of demography and some possible risk factors on the prevalence of artemisinin antibodies.

\section{MATERIALS AND METHODS}

\section{A. Study Population}

This study was conducted in Benin City, Nigeria with a total of 400 randomised participants (234 males and 166 females) clinically and laboratorily confirmed to have malaria parasite infection with evidence of artemisinin resistance attending out-patients clinics or admitted in the wards of major hospitals in Benin City, Nigeria. A structured questionnaire was used to collect data on sociodemography and informed consent was obtained from all participants or their parents/guardians in case of children prior to specimen collection. All malaria infected patients who have taken an artemisinin therapy at least once and 
presenting with both clinical symptoms and diagnostic features of malaria parasite infection were included in the study. While those not willing to give consent and/or had no history of previous exposure to artemisinin were excluded from the study. This study was approved by the Ethics and Research Committee of Edo State Ministry of Health, Benin City, Nigeria.

\section{B. Specimen Collection}

Blood (10mL) was collected from each study participant and dispensed in $5 \mathrm{ml}$ amount into plain and EDTA containers. The blood in the plain container was allowed to clot and the serum obtained was used to detect antibodies to artemisinin. The blood specimens in the EDTA container was used for $\mathrm{ABO}$ and Rhesus blood grouping as well as Haemoglobin phenotypes.

\section{Malaria Microscopy}

Malaria was diagnosed by examination of stained thick blood films as previously described by Akinbo et al [19]. Briefly, thick and thin film was made from each blood specimen and stained in $10 \%$ Giemsa stain for 30 minutes. The film was examined using oil immersion lens and a total of 200 fields per film was examined. The Plasmodium spp. present was identified and the parasite density was calculated from Giemsa stained thick blood film by multiplying the ratio of number of malaria parasite to 500 white blood cells by the patient white blood cells count to give malaria density in cells $/ \mathrm{ml}$.

\section{ABO and Rhesus Blood Grouping}

$\mathrm{ABO}$ and rhesus blood group were determined as previously described [20]. Briefly, a drop of each participant's blood was placed on three separate area of white tile. Each drop of blood mixed with a drop of commercially prepared antiserum $\mathrm{A}, \mathrm{B}$, and $\mathrm{D}$ respectively and observed for agglutination.

\section{E. Haemoglobin Phenotype}

The method described by Omoregie et al [21], was used for the determination of haemoglobin phenotype ( $\mathrm{Hb}$ phenotype). Cellulose acetate paper and tris- buffer, $\mathrm{pH} 8.5$ was used. Blood sample was applied on the paper after lysis in water. The strips then suspended in the genotype tank (Shandon 600X 100) with one end in each compartment filled with buffer. Standard $\mathrm{Hb}$ AA, AS, SS, SC and AC were spotted along with the test sample. The tank was then covered and electrophoresis carried out for 10 minutes at a potential difference of 220 volt. The strips were then removed and read macroscopically comparing the mobility of the test with standard $\mathrm{Hb} \mathrm{AA}, \mathrm{Hb} \mathrm{AS}$. Hb SS, Hb SC and $\mathrm{Hb} \mathrm{AC}$.

\section{F. Detection of Antibodies to Artemisinin}

Artemisinin antibodies were detected by both drugadsorption method and immune complex reaction as modified and described by Ikuoyogie et al [18]. Briefly, $0.5 \mathrm{~g}$ of pure artemisinin powder was dissolved in $10 \mathrm{ml}$ of normal saline.

Drug Absorption Method: Equal volumes of 10\% Human group $\mathrm{O}$ red cells and artemisinin solution was placed inside a test tube and incubated at $37 \mathrm{oC}$ for 30 minutes. After the incubation period, the drug red cell suspension was washed 4 times with normal saline to remove excess drug. Equal volumes of the drug-red cell mixture and patients serum was placed in a test tube and incubated at $37 \mathrm{oC}$ for $1 \mathrm{hr}$. This was followed by brief centrifugation and agglutination or haemolysis was watched out for. If negative, the entire mixture would be washed 4 times with normal saline. After washing, anti-human globulin (AHG) was added followed by brief centrifugation and agglutination or haemolysis was watched out for.

Immune Complex Method: Into a clean test tube was placed equal volumes of artemisinin, patient serum and 5\% human group $\mathrm{O}$ red cells, this was incubated at $37 \mathrm{oC}$ for $1 \mathrm{hr}$. This was be followed by brief centrifugation and agglutination or haemolysis was watched out for. If negative, the entire mixture would be washed 4 times with normal saline. After washing, anti-human globulin (AHG) was added followed by brief centrifugation and agglutination or haemolysis was watched out for.

Controls were performed in the same way for each of the methods with:-

1. Patients serum and group $\mathrm{O}$ red cells without drugs

2. Drug-red cell suspension without patient's serum.

Both controls gave negative results.

\section{G. Statistical Analysis}

The data obtained were analyzed with chi-square $(\chi 2)$ test using the statistical software GraphPad InStat version 2.05 for Windows 7, GraphPad Software, La Jolla California USA, www.graphpad.com.

\section{RESUlTS}

A total of $112(28.00 \%)$ out of the 400 participants had artemisinin antibodies. Although DAM detected more $(12.00 \%)$ of the antibodies, there was no significant difference $(\mathrm{p}=0.0562)$ in the rate of detection of the artemisinin antibodies amongst the methods used (Table I).

TABLE I: PREVALENCE OF ARTEMISININ ANTIBODIES IN RELATION TO METHODS OF DETECTION

\begin{tabular}{lcc}
\hline \multicolumn{2}{c}{ Artemisinin Antibody } \\
$\begin{array}{l}\text { Detection Method } \\
\mathbf{n}=\mathbf{4 0 0}\end{array}$ & No. Positive & Percentage \\
\hline $\begin{array}{l}\text { Drug Absorption Mechanism } \\
\text { (DAM) }\end{array}$ & 48 & 12.00 \\
$\begin{array}{l}\text { Immune complex reaction } \\
\text { (IMC) }\end{array}$ & 29 & 7.25 \\
$\begin{array}{l}\text { Drug Absorption Mechanism } \\
+ \text { Immune complex reaction }\end{array}$ & 35 & 8.75 \\
Total & $\mathbf{1 1 2}$ & $\mathbf{2 8 . 0 0}$ \\
\hline \hline
\end{tabular}

$\mathrm{n}=$ number tested; $\mathrm{p}=0.0562$

Gender, marital status, level of education, residential area and living arrangement did not significantly affect the prevalence of artemisinin antibodies. Participants aged 5865years had significantly higher $(\mathrm{p}=0.0244)$ artemisinin antibodies production. Also, ethnicity significantly affected the prevalence of artemisinin antibodies production $(\mathrm{p}=0.0001)$ as Igbo ethnic group recorded $58.62 \%$ as compared to others (Table II). 
TABLE II: PREVALENCE OF ARTEMISININ ANTIBODIES AND SOME ASSOCIATED RISK FACTORS.

\begin{tabular}{|c|c|c|c|c|c|}
\hline $\begin{array}{l}\text { Characteri- } \\
\text { stics }\end{array}$ & $\begin{array}{l}\text { Num- } \\
\text { ber of } \\
\text { pati- } \\
\text { ents } \\
\text { tested }\end{array}$ & $\begin{array}{l}\text { Number } \\
\text { Positive } \\
(\%)\end{array}$ & OR & $\begin{array}{c}95 \% \\
\text { CI }\end{array}$ & P-value \\
\hline Gender & & & 1.192 & $\begin{array}{c}0.76 \\
95 \\
1.85 \\
8\end{array}$ & 0.4949 \\
\hline Male & 234 & $62(26.50)$ & & & \\
\hline Female & 166 & $50(30.12)$ & & & \\
\hline Age (years) & & & & & 0.0244 \\
\hline $1-7$ & 55 & $9(16.36)$ & & & \\
\hline $8-14$ & 68 & $22(32.35)$ & & & \\
\hline $15-21$ & 79 & $22(27.85)$ & & & \\
\hline $22-28$ & 88 & $27(30.68)$ & & & \\
\hline $29-36$ & 38 & 11(28.95) & & & \\
\hline $37-43$ & 24 & $2(8.33)$ & & & \\
\hline $44-50$ & 19 & $7(36.84)$ & & & \\
\hline $51-57$ & 14 & $7(50.00)$ & & & \\
\hline $58-65$ & 9 & $5(55.56)$ & & & \\
\hline$\geq 66$ & 6 & $0(0)$ & & & \\
\hline Marital Status & & & & & 0.7436 \\
\hline Divorced & 5 & $2(40.00)$ & & & \\
\hline Married & 114 & $35(30.70)$ & & & \\
\hline Single & 271 & $73(26.93)$ & & & \\
\hline Widowed & 10 & $2(20.00)$ & & & \\
\hline $\begin{array}{l}\text { Education } \\
\text { Level }\end{array}$ & & & & & 0.2711 \\
\hline Non-formal & 118 & $26(23.21)$ & & & \\
\hline Primary & 81 & $27(24.11)$ & & & \\
\hline Secondary & 130 & $36(9.00)$ & & & \\
\hline Tertiary & 71 & $23(20.54)$ & & & \\
\hline Ethnicity & & & & & 0.0001 \\
\hline Igbo & 29 & $17(58.62)$ & & & \\
\hline Bini & 283 & $87(30.74)$ & & & \\
\hline Esan & 48 & $4(8.33)$ & & & \\
\hline Estako & 15 & $1(6.67)$ & & & \\
\hline Ijaw & 2 & $1(50.00)$ & & & \\
\hline Ika & 1 & $0(0)^{*}$ & & & \\
\hline Isoko & 1 & $0(0)^{*}$ & & & \\
\hline Owan & 7 & $1(14.29)$ & & & \\
\hline Urhobo & 9 & $0(0)^{*}$ & & & \\
\hline Yoruba & 5 & $1(20.00)$ & & & \\
\hline $\begin{array}{l}\text { Residential } \\
\text { Area }\end{array}$ & & & & & 0.4976 \\
\hline Rural & 18 & $3(16.67)$ & & & \\
\hline Sub-Urban & 28 & $9(32.14)$ & & & \\
\hline Urban & 354 & $\begin{array}{c}100(28.2 \\
5)\end{array}$ & & & \\
\hline $\begin{array}{l}\text { Living } \\
\text { Arrangement }\end{array}$ & & & & & 0.3943 \\
\hline Flat & 337 & $90(26.71)$ & & & \\
\hline One room & 20 & $8(40)$ & & & \\
\hline $\begin{array}{l}\text { Two rooms } \\
\text { Self-contain }\end{array}$ & 30 & 11(36.67) & & & \\
\hline Two Rooms & 13 & $3(23.08)$ & & & \\
\hline
\end{tabular}

Duration of the last artemisinin used and the mostly used brand of artemisinin did not significantly affect the production of artemisinin antibodies (Table III). The prevalence of artemisinin antibodies was not significantly affected by ABO blood group (0.3038), rhesus blood group
(0.8486) and haemoglobin phenotypes (0.6523) (Table IV).

TABLE III: PREVALENCE OF ARTEMISININ ANTIBODIES IN RELATION TO ARTEMISININ USAGE.

\begin{tabular}{lccc}
\hline \hline Characteristics & $\begin{array}{c}\text { Number of } \\
\text { patients } \\
\text { tested }\end{array}$ & $\begin{array}{c}\text { Number } \\
\text { Positive (\%) }\end{array}$ & P-value \\
\hline $\begin{array}{l}\text { Duration of the last } \\
\text { artemisinin use (months) }\end{array}$ & 167 & $42(10.5)$ & \\
$\leq 1$ & 106 & $33(8.3)$ & \\
2 & 26 & $7(1.8)$ & \\
3 & 101 & $30(7.5)$ & \\
$\geq 4$ & & & 0.2808 \\
Mostly used Artemisinin & & & \\
combination Therapy of & & & \\
Participants & 22 & $8(36.36)$ & \\
Amaterm & 15 & $1(6.67)$ & \\
Artequin & 16 & $7(43.75)$ & \\
Artesunate & 13 & $2(15.38)$ & \\
Camosunate & 52 & $17(32.69)$ & \\
Coartem & 6 & $1(16.67)$ & \\
Klariterm & 123 & $35(28.46)$ & \\
Lonart & 48 & $9(18.75)$ & \\
Lumartem & 92 & $27(29.35)$ & \\
P-Alaxin & & $5(38.46)$ & \\
D-Artep & 13 &
\end{tabular}

TABLE IV: EFFECT OF ABO, RHESUS BLOOD GROUPS AND HAEMOGLOBIN PHENOTYPES ON THE PREVALENCE OF ARTEMISININ ANTIBODIES.

\begin{tabular}{llll}
\hline \hline Characteristics & $\begin{array}{l}\text { Number of } \\
\text { patients } \\
\text { tested }\end{array}$ & $\begin{array}{l}\text { Number } \\
\text { Positive }(\%)\end{array}$ & $p$-value \\
\hline ABO blood group & 19 & $5(26.32)$ & 0.3028 \\
A & 9 & $0(0)$ & \\
AB & 10 & $3(30)$ & \\
B & 362 & $104(28.73)$ & \\
O & & $110(28.06)$ & \\
Rhesus blood group & 392 & $2(25)$ & \\
Positive & 8 & & \\
Negative & & $105(28.61)$ & \\
Haemoglobin & & $6(20.69)$ & \\
phenotypes & 367 & $1(25.00)$ & \\
AA & 29 & & \\
AS & 4 & & \\
SS & &
\end{tabular}

\section{DISCUSSION}

The emergence of Plasmodium falciparum resistant to chloroquine and some other antimalarial therapies led to the World Health Organisation recommendation of the use of artemisinin combination therapy (ACT) as a first line treatment for uncomplicated malaria [22]. Hence, early diagnosis of malaria with a corresponding treatment with ACT has been seen as key components of global malaria elimination programme [23]-[25]. This is mainly due to the fact that ACT effect rapid and sustained parasitological cure in patients with Plasmodium falciparum malaria and have shown to reduce transmission of this species in areas with moderate and low endemicity [26]-[28]. There is a significant increasing use of ACT in the treatment of malaria in hospitals in Nigeria [29]. Although ACTs have been 
reported to have mild and well tolerated adverse reaction on patients, there are recent reports on its capacity to cause haemolysis with a resultant severe autoimmune haemolytic anaemia when used in treating both complicated and uncomplicated malaria [14], [30]-[32]. There is no report on the prevalence of artemisinin antibodies in our environment; therefore, this study was conducted to fill this knowledge gap.

Our study revealed that $28.00 \%$ of the participants had artemisinin antibodies in their system. The presence of these drug-induced antibodies has an increased risk of haemolytic anaemia as there are several reports of delayed autoimmune haemolytic anaemia following the administration of artemisinin containing drug [14], [16], [30]-[35]. Although, there are no published data on the prevalence of artemisinin antibodies to compare our findings, the high prevalence observed in this study could be attributed to the WHO guideline for the use of artemisinin as the first line drug for the treatment of malaria and its consequential increased used in hospitals in Nigeria coupled with the poor regulation of use and misuse of antimicrobial agents in Nigeria [10], [22], [25], [29].

There was no significant difference $(\mathrm{p}=0.0562)$ in the rate of detection of the artemisinin antibodies by the different methods used, although DAM detected $12 \%$ of the participants while DAM and IMC detected $8.75 \%$ of the participants positive for artemisinin antibodies. Although the mechanism of the drug-induced haemolysis of artemisinin antibodies is unclear [14], [16]. The findings of this research indicate that antibodies to artemisinin can be detected by both methods with some cases being detected by only one method which is similar to the findings of Ikuoyogie et al [18], which though examined sulphadoxine antibodies. We therefore recommend that both methods be used for detection of artemisinin antibodies as there were instances where DAM method detected artemisinin antibodies and IMC method did not, and vice versa.

The transmission of malaria in Nigeria cuts across barriers posed by gender, age, marital status, educational status, ethnicity, residential area and living arrangement which makes the need for optimal care and control of malaria a task for both government and the populace [36]. The poor regulation of use and misuse of antimicrobial agents in Nigeria with large room for antimalarial use without prescription [37], [38] may attribute to the reason for the observed non-significant effect of gender $(\mathrm{p}=0.4949)$, marital status $(p=0.7436)$, educational status $(p=0.2711)$, residential area( $\mathrm{p}=0.4976)$ and living arrangement $(\mathrm{p}=0.3943)$ on the production of artemisinin antibodies amongst the study participants as most individuals indulge in self-medication regardless of their status on the aforementioned demographic factors. However, age and ethnicity significantly affected the production of artemisinin antibodies with the prevalence of artemisinin antibodies being significantly higher $(\mathrm{p}=0.0244)$ in subjects within the age range of 58-65years $(55.56 \%)$ and amongst subjects of Igbo ethnic extraction (58.62\%). Although there are limited data on the relationship between the use of anti-malaria and age as well as ethnicity, the study of Esan et al., (2018) [38] revealed that the Igbos were the second most involved ethnic group in self-medication in Nigeria after Hausa. Since
Hausa were not involved in our study, it follows that the high prevalence of artemisinin antibodies amongst the Igbo people in our study is due to the high indulgence in selfmedication by this ethnic group. Moreso that artemisinin had been a very effective first line anti-malaria drug in our locality and the Igbos being capitalist in nature [39]. The Igbos in other to maintain good health and not breakdown, they therefore may engage in over use of artemisinin thereby leading to the high prevalence of artemisinin antibodies. Artemisinin being a drug with a low adverse outcome is a drug of choice for individuals of all age groups but a recent study have shown that individuals between the ages of 25 54years have high preference for the use of artemisinin based combination therapy [40]. This can be attributed to the reason for the high prevalence of artemisinin antibodies observed within these age groups in our study.

The development of artemisinin antibodies may be due to the frequency of use of artemisinin and not the last time of use as there was no significant difference in the duration of the last time of artemisinin use in this study $(\mathrm{p}=0.7175)$. Although there are no data on the prevalence of artemisinin antibodies, the method used in this study detected $\operatorname{IgG}$ and IgM antibodies that take part in type II hypersensitivity reaction hence, it follows that those who took artemisinincontaining drugs within one month prior to specimen collection will have a higher dose of the drug in their system, thereby have higher titres of the antibodies in their system, this phenomenon was observed when individuals who took the drug in less than one month (10.5\%) were compared with those who took it within the last two months $(8.3 \%)$ and three months $(1.8 \%)$ before samples were obtained from them. This finding in the group of $\leq 1$ month to 3 months of the last use of artemisinin therapy agrees with the findings of Ikuoyogie et al [18], which though examined for sulphadoxine antibodies. The inconsistence in the prevalence for the antibodies in the group of those who took artemisinin within four months and beyond may be due to the broad nature of the group and physiological difference between the participants.

To delay or prevent emergence of resistance, artemisinins are combined with one of several longer-acting drugs amodiaquine, mefloquine, sulfadoxine/pyrimethamine or lumefantrine - which permit elimination of the residual malarial parasites [41]. This gave rise to different artemisinin combination therapies (ACT) with a complex clinical pharmacology with a suspected drug-drug interaction. However, there was no significant effect of the various combination therapies on the prevalence of artemisinin antibodies production in this study $(\mathrm{p}=0.2808)$. This may be due to the fact that artemisinin combination therapies are recommended to patients in most cases because of the presence of artemisinin and not because of the combined long-acting drug since ACT is recommended by $\mathrm{WHO}$ without a specification of a particular combination therapy [42].

In this study, it was observed that the prevalence of artemisinin antibodies was not significantly different amongst individuals of different ABO blood group $(\mathrm{p}=0.3028)$, rhesus blood group $(\mathrm{p}=0.8486)$ and haemoglobin phenotypes $(\mathrm{p}=0.6523)$. This implies artemisinin binds to red blood cells of individuals 
irrespective of their haemoglobin constituents or their $\mathrm{ABO}$ or rhesus blood group to activate antibody production using drug absorption mechanism. These findings are in line with the findings in previous study that have reported that there was no association of haemoglobin phenotypes, ABO and rhesus blood groups with the efficacy of artemisinin [43].

\section{CONCLUSION}

An overall prevalence of $28.00 \%$ artemisinin antibodies among patients with malaria was observed in this study. Age and ethnicity were identified as risk factors for the development of artemisinin antibodies; we therefore advocate the prudent use of artemisinin-containing antimalarial and concerted effort in combating selfmedication with ACT to avoid the development of resistance.

\section{ACKNOWLEDGMENT}

We appreciate the support of Mr. Elisha Osazemwinde who assisted in sample collection from participants.

\section{REFERENCES}

[1] WHO. World malaria report. World Health Organization: Geneva. 2013.

[2] WHO. World malaria report. World Health Organization: Geneva. 2017.

[3] Federal Ministry of Health (FMoH). National guidelines for diagnosis and treatment of malaria 2015. Abuja, Nigeria: FMoH. 2015.

[4] Centre for Disease Control and Prevention (CDC) Malaria. Global Health, Division of Parasitic Diseases and Malaria. U.S. Department of Health \& Human Services, USA.gov 2020.

[5] S.C. Murphy and J.G. Breman. Gaps in the Childhood Malaria Burden in Africa: Cerebral Malaria, Neurological sequelae, anaemia, respiratory distress, hypoglycemia, and complication of pregnancy. Am J Trop Med Hyg vol. 64, no. 1, pp. 57-67, Jan. 2001.

[6] B.H. Oladeinde, R. Omoregie, E.O. Osakue, and T.O. Onaiwu. Asymptomatic malaria among blood donor in Benin City, Nigeria. Iran J Parasitol vol 9, no. 3, pp. 415-422, Sep. 2014.

[7] R. M. Packard. The origins of antimalarial-drug resistance. New England Journal of Medicine vol. 371, pp. 397-399, 2012.

[8] E.A. Ashley, M. Dhorda, R. M. Fairhurst, C. Amaratunga, P. Lim, S. Suon et al. Spread of artemisinin resistance in Plasmodium falciparum malaria. New England Journal of Medicine. vol. 371, no. 5 pp. 411-423, Jul. 2014.

[9] K. M. Tun, M. Imwong, K. M. Lwin, A. A. Win, T. M. Hlaing, T. Hlaing et al. Spread of artemisinin-resistant Plasmodium falciparum in Myanmar: a cross-sectional survey of the K13 molecular marker. The Lancet Infectious Diseases. vol. 15, no. 4, pp. 415-421, Apr. 2015.

[10] I. N. Okeke, A. Lamikanra and R. Edelman. Socioeconomic and behavioral factors leading to acquired bacterial resistance to antibiotics in developing countries. Emerg Infect Dis vol. 5, no. 1, pp.18-27, Jan-Feb 1999.

[11] R. Omoregie and N. O. Eghafona. Urinary tract infection among asymptomatic HIV patients in Benin City, Nigeria. Br J Biomed Sci vol. 66, no. 4 pp.190-193, 2009.

[12] D. O. Ogbolu. Impact of ESBLs and CREs the Nigeria experience. APUA New Letter vol. 31, no. 2, pp. 15-16, Sep 2013.

[13] L. D. Elam-Evans, D. Yankey, J. A. Singleton and M. Kolasa. National, state, and selected local area vaccination coverage among children aged 19-35 months-United States, 2013. MMWR vol. 63, no. 34, p. 741, Aug 2014.

[14] L. Raffray, M. C. Receveur, M. Beguet, P. Lauroua, T. Pistone and D. Malvy. Severe delayed autoimmune haemolytic anaemia following artesunate administration in severe malaria: a case report. Malar. J. vol. 13 , no. 1, p. 398, Dec 2014.

[15] M. Charles, J. M. Patterson, L. Asadi and S. Houston. Delayed hemolysis after parenteral artesunate therapy for severe malaria in two returning Canadian travelers. Am J Trop Med Hyg vol. 93, no. 4, pp. 819-821, Oct 2015.
[16] S. Jauréguiberry, M. Thellier, P. A. Ndour, F. Ader, C. Roussel, R. Sonneville et al. Delayed-onset hemolytic anemia in patients with travel-associated severe malaria treated with artesunate, France, 2011-2013. Emerg. Infect. Dis. vol. 21, no. 5, p. 804, May 2015.

[17] R. Zhou, C. Yang, S. Li, Y. Zhao, Y. Liu, D. Qian et al. Molecular surveillance of drug resistance of Plasmodium falciparum isolates imported from Angola in Henan Province, China. Antimicrobial agents and chemotherapy. vol 1, no. 63, pp. e00552-519, Oct 2019.

[18] K. Ikuoyogie, H. O. Ogefere and R. Omoregie. Prevalence and risk factors for sulfadoxine antibody among patients undergoing treatment for malaria in Benin City, Nigeria. Oman Medical Journal. vol. 32, no. 3, pp. 207-213, May, 2017. DOI: 10.5001/omj.2017.39.

[19] F. O. Akinbo, P. J. Anate, D. B. Akinbo, R. Omoregie, S. Okoosi, A Abdulsalami et al. Prevalence of malaria among HIV patients on highly active antiretroviral therapy in Kogi State, North Central Nigeria. Ann. Nig. Med. vol. 10, no. 1, p. 11, Jan 2016.

[20] M. A. Emokpae and L. B. Akpologun. The use of atherogenic index of plasma in assessing the potential cardiovascular risk among $\mathrm{ABO}$ blood groups in sickle cell disease patients. Malay J Med Bio Res vol 2, no. 3 pp. $247-251,2015$

[21] R. Omoregie, H. O. Ogefere, E. U. Omokaro and E. Omorogbe. Distribution of $\mathrm{ABO}$ and rhesus blood group and haemoglobin phenotypes among tuberculosis patients in Benin City, Nigeria. J Med Lab Sci vol. 11, no. 1, pp. 68-70. 2002.

[22] C. C. Ezenduka, B. O. Ogbonna, O. I. Ekwunife, M. J. Okonta and C. O. Esimone. Drugs use pattern for uncomplicated malaria in medicine retail outlets in Enugu urban, southeast Nigeria: implications for malaria treatment policy. Malar J. vol. 13, no. 1, p. 243, Dec 2014 https://doi.org/10.1186/1475-2875-13-243

[23] V. I. Carrara, S. Sirilak, J. Thonglairuam, C. Rojanawatsirivet, S. Proux, V. Gilbos et al. Deployment of early diagnosis and mefloquine-artesunate treatment of falciparum malaria in Thailand the Tak Malaria Initiative. PLoS Medicine. vol. 3, no. 6, p. e183, Dec 2014. doi:10.1371/journal.pmed.0030183

[24] N. M. Douglas, N. M. Anstey, B. J. Angus, F. Nosten and R. N. Price. Artemisinin combination therapy for vivax malaria. The Lancet infectious diseases. vol. 10, no. 6 pp. 405-416, Jun 2010.

[25] World Health Organization. Guidelines for the treatment of malaria. World Health Organization; Aug 2015.

[26] F. Nosten, M. Van Vugt, R. Price, C. Luxemburger, K. L. Thway, A. Brockman et al. Effects of artesunate-mefloquine combination on incidence of Plasmodium falciparum malaria and mefloquine resistance in western Thailand: a prospective study. The Lancet. vol 356, no. 9226, pp. 297-302, July 2000.

[27] A. Bhattarao, A. S. Ali, S. P. Kachur, A. Martensson, A. K. Abbas, R. Khatib et al. Impact of artemisinin-based combination therapy and insecticide-treated nets on malaria burden in Zanzibar. PLoS Med vol. 4, pp. e309, 2007. doi: 10.1371/journal.pmed.0040309.

[28] D. Sinclair, B. Zani, S. Donegan, P. Olliaro and P. Garner. Artemisinin-based combination therapy for treating uncomplicated malaria. Cochrane Database Syst Rev. vol. 3, pp. CD007483, 2009.

[29] N. U. Igboeli, C. V. Ukwe and O. I. Ekwunife. Increasing use of artemisinin-based combination therapy for treatment of malaria infection in Nigerian hospitals. Pharmacy practice. vol. 8, no. 4, p. 243, Oct 2009. https://doi.org/10.4321/s1886-36552010000400007

[30] R. Adisa, T. O. Fakeye and D. Dike. Evaluation of adverse drug reactions to artemisinin-based combination therapy in a Nigeria university community. Tropical Journal of Pharmaceutical Research vol. 7, no. 2, pp. 937-944, 2008.

[31] F. Kurth, T. Lingscheid, F. Steiner, M. S. Stegemann, S. Bélard, N. Menner et al. Hemolysis after oral artemisinin combination therapy for uncomplicated Plasmodium falciparum malaria. Emerging infectious diseases. vol. 22, no. 8, pp. 1381-1386, Aug 2016 https://doi.org/10.3201/eid2208.151905

[32] S. Singh, S. K. Singh, A. K. Tentu, A. Kumar, B. Shahbabu, V. Singh et al. Artesunate-induced severe autoimmune hemolytic anemia in complicated malaria. Indian Journal of Critical Care Medicine vol. 22, no. $10, \quad$ pp. 753-756, Oct 2018 https://doi.org/10.4103/ijccm.IJCCM_298_18

[33] A. Corpolongo, P. De Nardo, P. Ghirga, E. Gentilotti, R. Bellagamba, C. Tommasi, et al. Haemolytic anaemia in an HIV-infected patient with severe falciparum malaria after treatment with oral artemetherlumefantrine. Malar J. vol. 11, p. 91, 2012.

[34] P. De Nardo, A. Oliva, M. L. Giancola, P. Ghirga, P. Mencarini, M. Bibas, et al. Haemolytic anaemia after oral artemether-lumefantrine treatment in a patient affected by severe imported falciparum malaria. Infection. vol. 41, no. 4, pp. 863-865, 2013.

[35] C. Hasegawa, M. Kudo, H. Maruyama and M. J. Kimura. Severe delayed haemolytic anaemia associated with artemether-lumefantrine treatment of malaria in a Japanese traveller. Journal of Infection and 
Chemotherapy. vol. 24, no. 3, pp. 216-219, Mar 2018 https://doi.org/10.1016/j.jiac.2017.10.008

[36] Federal Ministry of Health $(\mathrm{FmoH})$ and National Malaria Elimination Programme (NMEP). National malaria strategic plan 2014-2020. Abuja, Nigeria: FmoH and NMEP, 2014.

[37] G. I. Olasehinde, D. O. Ojurongbe, O. J. Akinjogunla, L. O. Egwari and A. O. Adeyeba. Prevalence of malaria and predisposing factors to antimalarial drug resistance in Southwestern Nigeria. Res J Parasitol. vol. 10, no. 3, pp. 92-101, 2015.

[38] D. T. Esan, A. A. Fasoro, O. E. Odesanya, T. O. Esan, E. F. Ojo and C. O. Faeji. Assessment of self-medication practices and its associated factors among undergraduates of a private university in Nigeria J Environ Public Health vol. 1, pp. 1-7, 2018 https://doi.org/10.1155/2018/5439079.

[39] J. C. Chukwu. Traditional Igbo economy: challenges to growth and development. JCSD vol. 10, pp. 70-77, 2015.

[40] S. C. Welle, O. Ajumobi, M. Dairo, M. Balogun, P. Adewuyi, B. Adedokun et al. Preference for artemisinin-based combination therapy among healthcare providers, Lokoja, North-Central Nigeria. Glob Health Res Policy. vol. 19, pp. 1-4, Jan 2019 Doi:10.1186/s41256-018-0092-9

[41] F. T. Aweeka and P. I. German. Clinical pharmacology of artemisinin-based combination therapies. Clinical Pharmacokinetics vol. 47, p. 91, Sep 2008. https://doi.org/10.2165/00003088200847020-00002

[42] A. Camara, L. F. Moriarty, T. Guilavogui, P. S. Diakite, J. S Zoumanigui, S. Sidibe, et al. Prescriber practices and patient adherence to artemisinin-based combination therapy for the treatment of uncomplicated malaria in Guinea, 2016. Malar J vol. 18, no. 1, p. 23, Jan 2019. Doi: 10.1186/s12936-019-2664-7.

[43] M. E. Boel, M. J. Rijken, B. J. Brabin, F. Nosten and R. McGready. The epidemiology of postpartum malaria: a systematic review. Malar J vol. 11, p. 114, Apr 2012.

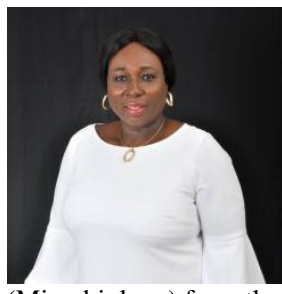

Helen Oroboghae OGEFERE was born about six decades ago in Oyede, Isoko North Loca Government Area, Delta State, Nigeria. She has a $\mathrm{Ph}$. D (Microbiology) from the University of Benin, Benin City, Nigeria (2007), M.Sc (Microbiology) from the University of Benin, Benin City, Nigeria (1991), FMLSCN (Haematology and Blood Group Serology) (1989), AMLSCN (Bacteriology) (1986), B.Sc. (Microbiology) from the University of Benin, Benin City, Nigeria (1984). She is an Associate Professor in the Department of Medical Laboratory Science, School of Basic Medical Sciences, College of Medical Sciences, University of Benin, Benin City, Edo State. Her research interest is in Medical Microbiology, Public Health Microbiology, Haematology and Blood Group Serology with over 50 research journal publication. She has supervised several Ph.D students and coordinates a research group that focuses mainly on microbial genetics and antimicrobial resistance.

Dr. Ogefere is a fellow of the West African Post Graduate College of Medical Laboratory Science and a member of several professional associations including the Association of Medical Laboratory Scientists of Nigeria, America Society of Microbiology, African Society for Laboratory Medicine etc.

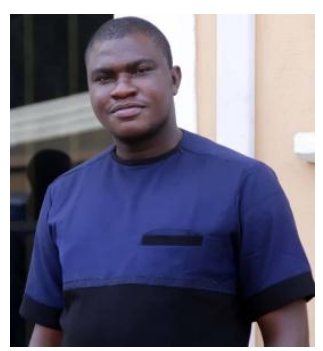

Nosakhare Lawrence IDEMUDIA is a medical Laboratory Scientist born and lives in Benin City, Nigeria about 4 decades ago. $\mathrm{He}$ is a doctoral student (Immunology and immunochemistry) in the department of Medical Laboratory Science University of Benin, Benin City, Nigeria and holds a Bachelors of medical laboratory science (B.MLS) degree from Ambrose Alli University, Ekpoma, Nigeria (2007) and M.Sc. in medical microbiology from University of Benin, Benin City, Nigeria (2015)

$\mathrm{He}$ is a Chief Medical Laboratory Scientist with the University of Benin Teaching Hospital. He has about 10 publications which focus more on antimicrobial susceptibility testing and resistance as well as opportunistic infections.

Mr. Idemudia is a member of the Association of Medical Laboratory Scientists of Nigeria, America Society of Microbiology, African Society for Laboratory Medicine. He is a Nation's Builder Merit Award recipient of the Nigerian Medical Laboratory Science Students Association.

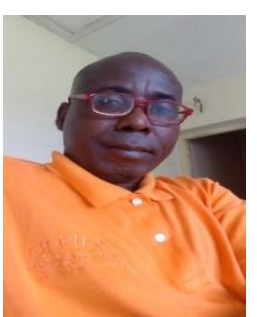

Richard OMOREGIE born in Benin City, Nigeria about 5 decades ago lives in Benin City as a Medical Laboratory Scientist with over 25years post qualification experience. He has also being involved in the teaching and training of Medical Laboratory Science students for more than 10years. He is a Fellow of the Medical Laboratory Science Council of Nigeria with an M. Phil in Medical Microbiology. His area of expertise includes medical microbiology, microbial resistance, molecular biology, opportunistic infections in the immunecompromised patients with emphasis on HIV, and to a lesser extent haematology and blood transfusion science.

He has reviewed manuscripts for many journals, most notably, African Health Sciences, Saudi Medical Journal, Notulae Scientifia Biologocae, to mention a few and has over 100 published articles, and an h-index of 15 or 14 (excluding self-citations)

Mr. Richard is member of the Association of Medical Laboratory Scientists of Nigeria. 